PRACE NAUKOWE UNIWERSYTETU EKONOMICZNEGO WE WROCŁAWIU

Nauki ekonomiczne w XXI wieku - wyzwania, dylematy, perspektywy

ISSN 1899-3192

Ekonomia, finanse, nauki o zarządzaniu

e-ISSN 2392-0041

\title{
Malgorzata Sztorc
}

Politechnika Świętokrzyska

e-mail: msztorc@tu.kielce.pl

\section{IMPLEMENTACJA KONCEPCJI \\ ORGANIZACJI SIECIOWEJ W PROCESIE ZDOBYWANIA PRZEWAGI KONKURENCYJNEJ PRZEZ PRZEDSIĘBIORSTWA HOTELARSKIE}

\section{IMPLEMENTING THE CONCEPT OF NETWORK ORGANIZATION IN THE PROCESS OF GAINING COMPETITIVE ADVANTAGE BY HOTEL BUSINESESS}

DOI: $10.15611 /$ pn.2017.499.27

JEL Classification: L14, L22, Z32

Streszczenie: Aktualne otoczenie społeczno-gospodarcze funkcjonowania przedsiębiorstw hotelarskich charakteryzuje się coraz większym natężeniem działań konkurencyjnych. W konsekwencji nie każda organizacja potrafi sprostać współczesnym wyznaniom otoczenia będącym rezultatem działalności w zmiennym otoczeniu. Wobec tego część z nich szuka nowych rozwiązań służących podnoszeniu konkurencyjności i zdobywaniu przewagi konkurencyjnej. Jednym ze sposobów jej osiągnięcia jest tworzenie powiązań i związków z innymi przedsiębiorstwami. Celem artykułu jest wskazanie możliwości implementacji podejścia sieciowego w sektorze usług hotelarskich z wykorzystaniem analizy empirycznej oraz rekomendacji sposobu organizacji procesu strategicznego zarządzania hotelem. W artykule przedstawiono wyniki krytycznej analizy literatury z perspektywy rozpoznania $\mathrm{i}$ zastosowania potencjalnych koncepcji powiązań sieciowych. Na podstawie analizy literatury oraz badań prowadzonych metodą ankietową określono sposoby zdobywania przewagi konkurencyjnej, a także opracowano rekomendacje dla procesu zarządzania strategicznego hoteli funkcjonujących w sieci.

Słowa kluczowe: organizacja sieciowa, przewaga konkurencyjna, hotelarstwo, strategia.

Summary: The growing intensity of competitive activities is typical of the modern socio-economic environment in which hotel businesses operate. As a consequence of this process, not all organizations are able to meet the contemporary challenges which result from operating in a variable environment. For that reason some of them are looking for new solutions to improve their competitiveness and gain competitive advantage. One way is to create linkages and relationships with other companies. The purpose of this paper is to indicate the possibility of implementing a network approach in the hotel business sector both on the example of empirical analysis and during the organization of the process of strategic hotel management. The paper presents the results of critical literary analysis from the perspective of distinguishing 
and applying the potential concepts of network linkages. The methods of gaining competitive advantage were identified on the basis of the literature analysis and research. The paper also includes the recommendations developed for the process of strategic management of hotels operating within the network.

Keywords: network organization, competitive advantage, hotel industry, strategy.

\section{Wstęp}

Zmiany, które współcześnie zachodzą w standardach funkcjonowania przedsiębiorstw oraz wpływające na nie procesy globalizacji, postępująca dywersyfikacja działalności w zakresie geograficznym oraz kulturowym implikują konieczność zapewnienia im dostępu do wiedzy na temat określonych rynków, procesów, produktów i technologii. W rezultacie otoczenie hoteli przekształca się w coraz bardziej niepewne. Sytuacja tego rodzaju obliguje przedsiębiorstwa do wykreowania odpowiednich reakcji na zachodzące zamiany rynkowe oraz wskazuje na konieczność zastosowania formy dekompozycji ryzyka działalności. Natychmiastowe rezultaty, których spodziewają się przedsiębiorstwa hotelowe, nie pozwalają na zrównoważone kreowanie wszechstronnej wiedzy, umiejętności oraz skoncentrowanie na kluczowych zasobach umożliwiających efektywne ich funkcjonowanie. W związku z tym hotele zazwyczaj korzystają z pomocy podmiotów zewnętrznych, które w sposób niezależny wzmacniają ich zdolności i powiększają zasoby. W ten sposób kształtowane są typowe sieci kooperujących ze sobą podmiotów. Charakterystycznym miernikiem przedsiębiorstw przyjmujących postać sieci jest posiadanie wyjątkowej kategorii wiedzy. Podstawę ich funkcjonowania stanowi dzielenie się wiedzą między podmiotami pozostającymi w relacji sieciowej.

Współczesny proces zarządzania strategicznego, analizowany z perspektywy współpracy sieciowej oraz powstających więzi, polega na tworzeniu źródeł przewagi konkurencyjnej (przewagi). Dotychczas w literaturze przedmiotu wśród głównych nurtów zarządzania strategicznego rozpatrywano problemy strategiczne $\mathrm{z}$ punktu widzenia teorii ograniczeń, wyboru strategicznego oraz założeń konkurencji. Natomiast analiza wpływu powiązań sieciowych na przewagę konkurencyjną podmiotów gospodarczych zrealizowana została w stopniu fragmentarycznym. Na ogół literatura przedmiotu dotyczy badań przewagi konkurencyjnej całych sieci lub grup przedsiębiorstw. Niemniej jednak przypuszcza się, że rzeczywista walka konkurencyjna występuje nie pomiędzy indywidualnymi podmiotami, ale wśród sieci międzyorganizacyjnych. Natomiast występujące uwarunkowania kreowania sieci implikują zanik konkurencji w gronie indywidualnie funkcjonujących hoteli. Dlatego też przedsiębiorstwa podporządkowane tego typu relacjom tworzą przewagę konkurencyjną dla całej sieci, jak i bezpośrednio sieć kształtuje przewagę hoteli.

Celem artykułu było wskazanie na możliwość implementacji podejścia sieciowego w przedsiębiorstwach hotelowych celem uzyskania przewagi konkurencyjnej. 
W artykule przedstawiono wyniki krytycznej analizy literatury z perspektywy rozpoznania i zastosowania potencjalnych koncepcji powiązań sieciowych. Na podstawie przeprowadzonej analizy literatury oraz badań określono metody zdobywania przewagi konkurencyjnej, a także opracowano rekomendacje dla procesu zarządzania strategicznego hoteli funkcjonujących w sieci.

\section{Modele przewagi konkurencyjnej w hotelarstwie}

Współcześnie funkcjonujące przedsiębiorstwa hotelarskie, aby osiągnąć przewagę, zobowiązane są do uzyskania określonego poziomu konkurencyjności. Wobec tego należy uznać, iż konkurencyjność stanowi kluczowe kryterium obecności organizacji w systemie gospodarczym. Niemniej jednak do równie istotnych zaliczyć należy także zysk oraz udział w rynku. W momencie uruchomienia działalności konkurencyjność nie stanowi ich celu strategicznego. Mimo to hotele próbują wyróżniać się wśród podmiotów konkurencyjnych. Metody osiągnięcia tych celów rekomendują przesłanki sukcesywnego ich rozwoju.

Konkurencyjność jest koncepcją zaliczaną do kategorii sformułowań ekonomicznych, która posiada interdyscyplinarne i wielowymiarowe znaczenie. W literaturze przedmiotu rozpatrywane są zróżnicowane stanowiska dotyczące parametrów ją wyróżniających. Z kolei w praktyce zdefiniowano wiele poglądów dotyczących determinant konkurencyjności przedsiębiorstw. Ograniczenie wynikające z braku możliwości sprecyzowania terminu konkurencyjności stanowi zakres jego rozpatrywania. Zazwyczaj charakteryzowana jest ona z pespektywy parametru warunkującego osiągniecie lepszych rezultatów w porównaniu do podmiotów konkurencyjnych [Gorynia 2000, s. 96-103]. Należy zauważyć, iż badanie konkurencyjności w kontekście wieloznaczności skutkuje jej identyfikowaniem z przewagą lub pozycją konkurencyjną.

Ukierunkowanie badawcze wskazane przy interpretacji tego pojęcia potwierdza, że nie posiada ono wyjaśnienia wskazanego explicite. Konkurencyjność przedsiębiorstw charakteryzuje się zdolnością do osiągania lub utrzymywania przewagi konkurencyjnej. Interpretowana $w$ ten sposób, może być ona uważana za odpowiednik zdolności konkurencyjnej firmy [Gorynia 2010, s. 77]. W literaturze przedmiotu wyróżnić można także definicje charakteryzujące konkurencyjność z perspektywy zdolności przedsiębiorstwa do długookresowego, efektywnego wzrostu. Wówczas do istotnych jej komponentów zalicza się elastyczność oraz ekspansywność [Bakier, Meredyk 2000, s. 38]. Natomiast S. Yonggang podkreśla, że konkurencyjności przedsiębiorstw należy poszukiwać w zdolności do uczenia się i kreatywności. Bowiem umożliwiają one połączenie ogółu kluczowych czynników, do których należy zaliczyć: zasoby, wiedzę, narzędzia, zarządzanie i strategię [Yonggang 2006, s. 71-72].

W sposób ogólny należałoby stwierdzić, iż przedsiębiorstwo hotelarskie odznacza się konkurencyjnością, jeżeli jest w stanie wykreować przewagę konkurencyjną, 
która wykazuje jego potencjał. Ponadto stanowi ona system powiązany z kompetencjami będącymi następstwem procesu dostosowania się do zmian zachodzących w otoczeniu.

Przewaga konkurencyjna oraz pozycja konkurencyjna należą do nadrzędnych terminów zgłębianych $\mathrm{w}$ wielu podejściach dotyczących funkcjonowania i rozwoju organizacji. Niemniej jednak w literaturze przedmiotu nie występuje jednoznaczne ujęcie, które określałoby analizowaną problematykę. Uzasadnieniem sytuacji tego rodzaju jest wieloaspektowa istota prezentowanego zagadnienia oraz wielostronne jej rozpoznawanie i wymiarowanie.

Zaprezentowane koncepcje umożliwiają zdefiniowanie pojęcia przewagi konkurencyjnej jako umiejętności budowania nowych elementów konkurencyjności szybciej niż robią to rynkowi rywale [Adamik 2008, s. 10]. Przewaga konkurencyjna z pominięciem celów strategicznych stanowi zasadniczy model zarządzania strategicznego niezależnie od prezentowanych w literaturze kierunków rozwoju, szkół lub całościowych koncepcji. Powszechnie uznana jest za komponent wywodzący się z konkurencji i konkurencyjności, którego problematyka wzbudza zainteresowanie zarówno teorii, jak i praktyki. Oznacza ona możliwość osiągnięcia kluczowej pozycji przez organizację w stosunku do większego grona konkurentów. Ponadto odzwierciedla stosunkowy poziom operowania przedsiębiorstwa na rynku, zapewniając tym samym nabywcy usługi/produkty dostosowane do jego wymagań, ale posiadające atrakcyjniejsze właściwości niż zaproponowane przez podmioty konkurencyjne.

Zazwyczaj hotel osiąga przewagę konkurencyjną, gdy potrafi wygenerować więcej wartości ekonomicznej w porównaniu do obiektów konkurencyjnych [Barney 2011, s. 15]. Przewaga charakteryzowana jest także jako zdolność do takiego wykorzystywania potencjału konkurencyjności, aby umożliwić racjonalne tworzenie atrakcyjnej oferty rynkowej oraz skutecznych instrumentów konkurowania zapewniających powstanie wartości dodanej [Stankiewicz 2005, s. 15].

Konkurencyjne przedsiębiorstwo hotelowe powinno wyróżniać się umiejętnością i elastycznością przystosowania do zmieniających się warunków rynkowych, w których funkcjonuje, oraz zmierzać do podejmowania decyzji biznesowych zapewniających mu uzyskanie długookresowej przewagi konkurencyjnej. Należy zwrócić uwagę, iż w dynamicznym otoczeniu przedsiębiorstwo zmuszone jest do szybkiej reakcji celem neutralizowania przewagi konkurentów. Podejście tego rodzaju zobowiązuje do natychmiastowej rekonfiguracji zasobów oraz wzmocnienia stosownych źródeł przewagi. W rezultacie, zamiast długotrwałej przewagi, przedsiębiorstwo kształtuje szereg następujących po sobie przewag tymczasowych. Długotrwałą przewagę przedsiębiorstwa hotelarskiego tworzy długookresowa korzyść z wdrażania unikalnej strategii kreującej wartość, niepowielana równocześnie przez żadnego z obecnych lub potencjalnych konkurentów, którzy w rezultacie pozbawieni są korzyści z nią związanych [Śmigielska 2007, s. 16]. Podejście długookresowej przewagi konkurencyjnej traci ważność, ponieważ współcześnie występujące warunki rynko- 
we podają w wątpliwość możliwość kreowania trwałej przewagi. W literaturze przedmiotu coraz więcej zwolenników zyskuje koncepcja tymczasowej przewagi, uznawana za reakcję na fundamentalne zmiany [Penc-Pietrzak 2015, s. 144].

Przewaga konkurencyjna analizowana może być z punktu widzenia trzech perspektyw: zasobów, powszechności oraz zdolności wykonania. Płaszczyzny tego rodzaju powinny wykazywać dwie orientacje strategiczne polegające na: 1) tworzeniu wartości organizacji oraz 2) zmniejszeniu suwerenności strategicznych zachowań konkurentów. Strategie rozwoju hoteli powinny zmierzać do wyznaczenia punktów i sposobów zdobywania przewagi konkurencyjnej [Harasim 2012, s. 15]. Strukturę przewagi konkurencyjnej wynikającą ze strategicznej orientacji przedsiębiorstwa przedstawiono $\mathrm{w}$ tab. 1 .

Tabela 1. Kluczowe źródła przewagi konkurencyjnej organizacji

\begin{tabular}{|l|l|l|}
\hline $\begin{array}{l}\text { Wymiary przewagi } \\
\text { konkurencyjnej }\end{array}$ & \multicolumn{1}{|c|}{$\begin{array}{c}\text { Orientacja strategiczna } \\
\text { na tworzenie wartości firmy }\end{array}$} & \multicolumn{1}{|c|}{$\begin{array}{c}\text { Orientacja strategiczna } \\
\text { na ograniczenie swobody } \\
\text { manewru strategicznego rywali }\end{array}$} \\
\hline $\begin{array}{l}\text { Posiadanie na } \\
\text { własność }\end{array}$ & $\begin{array}{l}\text { Aktywne pozyskiwanie } \\
\text { i gromadzenie zasobów oraz } \\
\text { kompetencji tworzące bogactwo } \\
\text { organizacji }\end{array}$ & $\begin{array}{l}\text { Zawężenie swobody manewru } \\
\text { konkurentów w tworzeniu zasobów } \\
\text { i kompetencji cennych } \\
\text { z perspektywy strategicznej }\end{array}$ \\
\hline $\begin{array}{l}\text { Dostęp do zasobów } \\
\text { i kompetencji }\end{array}$ & $\begin{array}{l}\text { Tworzenie dostępu do zasobów } \\
\text { i kompetencji poprzez budowanie } \\
\text { sieci powiązań z różnymi } \\
\text { interesariuszami (dostawcami, } \\
\text { odbiorcami, klientami) }\end{array}$ & $\begin{array}{l}\text { Blokowanie dostępu konkurentom } \\
\text { do potencjalnie cennych zasobów } \\
\text { i kompetencji z punktu widzenia } \\
\text { strategicznego (wysokiej klasy } \\
\text { specjalistów) }\end{array}$ \\
\hline $\begin{array}{l}\text { Efektywność } \\
\text { wykonania oparta } \\
\text { na nieustannym } \\
\text { doskonaleniu }\end{array}$ & $\begin{array}{l}\text { Kształtowanie uczenia się } \\
\text { w działaniu służące osiąganiu } \\
\text { przez ludzi wysokiego poziomu } \\
\text { efektywności }\end{array}$ & $\begin{array}{l}\text { Opóźnianie organizacyjnego uczenia } \\
\text { się konkurentów, celem zachęcenia } \\
\text { ich do efektywnego kreowania } \\
\text { nowych kompetencji i stworzenia im } \\
\text { barier rozwoju }\end{array}$ \\
\hline
\end{tabular}

Źródło: [Bartnicki 2001, s. 17].

Przewaga konkurencyjna stanowi więc bazowy cel strategiczny przedsiębiorstwa hotelowego oraz główny czynnik długotrwałego powodzenia organizacji. Przesłankę jej osiągnięcia i utrzymania stanowi proces efektywnego zarządzania strategicznego.

Pod koniec XX w. w wyniku nurtu nowej ekonomii instytucjonalnej J. Dyer i H. Singh wykreowali relacyjny model przewagi konkurencyjnej [Dyer, Singh 1998, s. 660], nazywany również modelem międzyorganizacyjnym. Autorzy paradygmatu uważają, iż większe znaczenie dla rynkowego funkcjonowania przedsiębiorstw mają relacje niż posiadane zasoby. Zdefiniowali oni także w inny sposób niż M.E. Porter otoczenie przedsiębiorstwa. Autorzy charakteryzują je nie jako siły, lecz strukturę podmiotów, z którymi przedsiębiorstwa integrują wielopłaszczyznowe relacje. 
W modelu tego rodzaju przewaga konkurencyjna oparta jest na relacjach podmiotów oraz zachodzących w praktyce gospodarczej połączeniach, które ukierunkowane są na współpracę stanowiącą fundament tworzenia sieci. Właściwe zestawienie komplementarnych zasobów i zdolności powinno w podobny sposób pozwolić na kształtowanie innowacyjnych usług/produktów, wymianę informacji ze zbiorowym tworzeniem wiedzy oraz umożliwić redukcję kosztów transakcyjnych.

\section{Organizacje sieciowe źródłem kooperacji w hotelarstwie}

Organizacje sieciowe uznaje się za relatywnie nowoczesne formy funkcjonowania współczesnych przedsiębiorstw hotelarskich. Ich powstanie i rozwój należałoby połączyć z powiązaniami kooperacyjnymi. Proces kreowania długoterminowych i trwałych więzi pomiędzy przedsiębiorstwami funkcjonuje od kilkudziesięciu lat. Nietypowy charakter tego rodzaju struktury pierwotnie nie wykazywał zainteresowania badaczy, dlatego też usytułowany został w zakresie nauk o zarządzaniu. Początkowo kooperacja organizacji sieciowej odnosiła się do marginalnych działań podejmowanych celem realizacji kompleksowej strategii kooperujących przedsiębiorstw.

Transformacja więzi kooperacyjnych przyczyniła się do wzrostu zainteresowania problematyką organizacji sieciowych. Na przełomie lat 70. i 80 . XX wieku ukazały się pierwsze opracowania, które $\mathrm{w}$ szerszym zakresie charakteryzowały analizowaną problematykę. Natomiast na początku lat 90 . XX w. w związku z intensyfikacją procesów globalizacyjnych nastąpiło zwiększone zainteresowanie sposobem funkcjonowania organizacji sieciowych. Aktualnie w międzynarodowej literaturze wiele pozycji koncentruje się na analizie tej koncepcji organizacji przedsiębiorstwa. Mimo to występuje luka badawcza, która wynika z systematyzacji zjawiska i wyeksponowania założeń w sposób zdecydowanie odróżniający związki sieciowe od innych związków transakcyjnych występujących wśród podmiotów.

Współczesne organizacje sieciowe kształtują się na gruncie nowego podejścia do konkurencji, która utożsamiana jest nie tylko z indywidualnymi zdolnościami przedsiębiorstw, ale z umiejętnościami wynikającymi z kooperacji w sieci wspólnych wartości. Ich istotę stanowi podzielona kontrola nad wyspecjalizowanymi i powiązanymi ze sobą zasobami, które z reguły posiadają niematerialny charakter. Organizacje sieciowe kreowane są wówczas, gdy występuje potencjał strategiczny wśród partnerów organizacji, który tworzy wartość dodaną, stanowiącą jednocześnie czynnik warunkujący konkurencyjność podmiotów tworzących sieć [Mikołajek-Gocejna 2011, s. 332-333]. W literaturze przedmiotu występuje wiele ujęć i definicji terminu organizacji sieciowej.

Termin „sieć” stopniowo uznawany zostaje za pojęcie macierzyste, które ma zastąpić stanowisko zwyczajowo pojmowanego rynku. W zestawieniu z wybranym podejściem organizacja sieciowa może stanowić: współczesną formę organizacji, nową metodę zarządzania bądź nowoczesny model zorganizowania stosunków za- 
chodzących między odrębnymi podmiotami gospodarczymi [Benassi, Greve, Harkola 1999, s. 208]. Zatem sieć międzyorganizacyjna może być analizowana jako system współdziałania niezależnych pod względem organizacyjno-prawnym organizacji, zjednoczonych kapitałowo, jak również niepowiązanych zasobami finansowymi, ale każdorazowo bazujący na potencjale strategicznym podmiotów sieci w jednym lub wielu obszarach funkcjonowania, jak też na wielowymiarowej współpracy [Drabik 2016, s. 75]. Tym samym sieć nie stanowi formy organizacyjnej, która sama w sobie generuje przewagę i podnosi efektywność funkcjonowania. Natomiast funkcjonuje w charakterze narzędzia, które odpowiednio zastosowane, pozwala działać skuteczniej w burzliwym otoczeniu [Czakon 2012, s. 17]. Sieć organizacyjna postrzegana jest także jako system stworzony dobrowolnie przez wiele organizacji celem współpracy w perspektywie strategicznej. Ze względu na sposób realizacji celów strategicznych stanowi system, który [Wyrwicka 2011, s. 40-43]:

1) zapewnia podmiotowi gospodarczemu przetrwanie i wzmocnienie pozycji konkurencyjnej za pomocą wielostronnych relacji współpracy,

2) umożliwia koncertowanie się na kluczowych umiejętnościach, które są aktywizowane i wykorzystywane w sposób skoordynowany,

3) umożliwia inteligentne i kolektywne korzystanie z zasobów sieci oraz potencjału wiedzy.

Natomiast zasadniczą przesłanką podejścia sieciowego jest współpraca dwóch lub większej liczby podmiotów, z perspektywą utrzymania zachodzących pomiędzy nimi stosunków konkurencyjnych [Nowacki 2014, s. 17].

Istotę sieci organizacyjnej stanowi osiągnięta więź przedsiębiorstw składających się na jej strukturę. Sieci przedsiębiorstw w literaturze przedmiotu utożsamiane są z określeniami: sieci międzyorganizacyjne, organizacja sieciowa, struktura sieciowa, sieć organizacyjna, organizacja o charakterze sieci, przedsiębiorstwa sieciowe, system sieciowy, sieci przedsiębiorstw, sieci przemysłowe, sieci biznesowe, organizacja pajęczynowa, korporacja sieciowa, network, sieć organizacji, strategiczne sieci korporacji, sieci rynkowe, sieci gospodarcze, struktury sieciowe przedsiębiorstw. W wymiarze organizacyjnym sieci rozumiane są jako samodzielne pod względem formalno-prawnym podmioty kooperujące $\mathrm{w}$ celu wytworzenia wartości, a podstawową ich cechą jest brak hierarchii [Czakon 2012, s. 15].

W definicjach mających na celu wyjaśnienie pojęcia organizacji sieciowej autorzy jednoznacznie zwracają uwagę na istotę relacji wewnętrznych. Zatem bazuje ona na więziach występujących między przedsiębiorstwami tworzącymi strukturę danej sieci. Wobec tego należy wnioskować, iż sieć stanowi układ co najmniej dwóch organizacji zaangażowanych w relację długoterminową [Thorelli 1986, s. 37]. Struktura sieciowa pełni rolę nowoczesnej formy organizacji, która ukazuje sposób zorganizowania wzajemnych stosunków między firmami lub (i) jednostkami składowymi pojedynczego przedsiębiorstwa [Mikuła 2006, s. 53]. Podejście sieciowe oznacza również system powiązań występujących między organizacjami, niekoniecznie zobowiązanymi do kreowania formalnych struktur. Fundamentalne założenie organi- 
zacji sieciowej stanowi kooperacja dwóch lub większej liczby podmiotów z perspektywą zachowania występujących pomiędzy nimi stosunków konkurencyjnych.

Kooperacja i integracja podmiotów przyjmuje układ, w którym można wyróżnić trzy podstawowe struktury powiązań sieciowych [Wiatrak 2003, s. 12]: 1) pionową zwaną wertykalną - uwzględnia wspólne działania w obrębie faz produkcji, dystrybucji oraz sprzedaży danego wyrobu; 2) poziomą (horyzontalną) - polega na połączeniu firm zajmujących się produkcją tego samego dobra/usługi; 3) okresową część zleceń przekazywana jest innej firmie wytwarzającej ten sam produkt/usługę.

Ponadto sieci międzyorganizacyjne przybierają także postać: zintegrowaną, sfederowaną, kontraktową, stosunków bezpośrednich, społeczną, biurokratyczną, lokalną, globalną [Brilman 2002, s. 427; Mikuła 2006, s. 76-77; Todeva 2010, s. 133]. W literaturze przedmiotu przedstawiono następującą koncepcję modelu sieciowego, w którym [Piwoni-Krzeszowska 2015, s. 324]:

- otoczenie organizacji nie jest bezimienne ani anonimowe,

- otoczenie organizacji nie jest zatomizowane,

- organizacja częściowo kontroluje otoczenie,

- zasoby nie muszą być hierarchicznie kontrolowane,

- szanse istnieją w sieci, która je dostrzega, warunkuje i umożliwia ich wykorzystanie,

- przewaga konkurencyjna zależy od struktur, pozycji relacji w sieci,

- warunki otoczenia mogą być stabilizowane sieciami,

- motywem kształtowania relacji jest dążenie do uzyskania renty relacyjnej Colemana,

- kształtowanie relacji ma na celu budowanie więzi,

- działanie podmiotów jest uwarunkowane strukturami więzi wewnątrz- i międzyorganizacyjnych.

Współcześnie strategia wzajemnej kooperacji stanowi popularny wariant rozwoju przedsiębiorstw hotelarskich. Tym samym determinuje ona zewnętrzne motywy prowadzenia działalności gospodarczej we współczesnym biznesie posiadające źródło w mikrootoczeniu i otoczeniu sektorowym organizacji. W następstwie kreowania nowych czynników rynkowego funkcjonowania, podmioty zobowiązane są wyboru określonego wariantu strategicznego, tj. jednej ze strategii: wzrostu, stabilności, obrony lub mieszanej. Natomiast do sposobów wzrostu rynkowego przedsiębiorstw zaliczamy: strategię koncentracji, integracji, dywersyfikacji. Wymienione możliwości strategiczne mogą być realizowane z perspektywy dychotomicznej. $Z$ reguły polegają one na rozwoju wewnętrznym przez wykorzystywanie zasobów i umiejętności przedsiębiorstwa. Ewentualnie za pomocą rozwoju zewnętrznego przez nabycie innej firmy, fuzji lub przedsięwzięcie partnerskie z innym przedsiębiorstwem [Chwistecka-Dudek 1993, s. 52].

Organizacja sieciowa wyróżnia się nietypowymi parametrami, które zapewnia im osiągnięcie przewagi konkurencyjnej. Koncepcja podmiotów tego typu stanowi nowy sposób tworzenia i utrzymywania przewagi konkurencyjnej. Relacje w ra- 
mach sieci polegają na wsparciu wynikającym z posiadanych zasobów, które kontrolowane są przez drugą stronę. W ten sposób przedsiębiorstwa osiągają korzyści z uzyskiwanych zasobów. Zatem powiązania kooperacyjne kształtowane są wówczas, gdy istnieje potencjał strategiczny pomiędzy podmiotami. Tworzy on wartość dodaną, która jednocześnie stanowi przyczynę konkurencyjności przedsiębiorstw należących do sieci. Źródeł konkurencyjności należy upatrywać także w korzystnych okolicznościach, które sprzyjajątworzeniu sieci. Należy donichzaliczyć [Pietruszka-Otryl 2007, s. 167]: 1) nieprzewidywalność, niepewność i zmienność rynku bądź średnie rozmiary rynku; 2) brak możliwości dokonania strategicznej akcji zakupu przez konkurentów z branży lub spoza niej w sytuacji atrakcyjnego rynku; 3) brak zainteresowania dokonaniem zakupu wynikającym z nieatrakcyjnego charakteru rynku i konkurencji; 4) incydentalny charakter wspólnie realizowanych przedsięwzięć.

Sieć stanowi formę organizacji funkcjonującej w celu zbudowania przewagi konkurencyjnej. Dlatego też występują w niej pewnego rodzaju relacje pomiędzy odrębnymi podmiotami. Zakres tych relacji wyróżnia się w znacznym stopniu współdziałaniem niż konkurencyjnością [Zentes, Awoboda, Morschett 2005, s. 6]. W związku z tym koncepcja tworzenia i funkcjonowania sieci związana jest z zagwarantowaniem i umocnieniem pozycji konkurencyjnej, która kreowana jest za pomocą różnych form współdziałania organizacji w celu uzyskania dostępu do strategicznych zasobów [Glückler i in. 2012, s. 29].

Wobec tego zarządzanie ukierunkowane jest na rozpoznanie metody dostępu do kluczowych zasobów zewnętrznych. Struktura sieciowa umożliwia redukcję nakładów niezbędnych w procesie wprowadzenia nowego asortymentu na rynek. Ponadto usprawnia kreowanie i wspomaga przewagę konkurencyjną przez koncentrację ograniczonych zasobów wewnętrznych.

\section{Organizacja sieciowa jako metoda zdobywania przewagi na rynku hotelarskim}

Współczesne przedsiębiorstwa hotelowe stosują podobne metody wobec nietradycyjnych perspektyw rozwoju. Wykorzystują one różne taktyki polegające na eliminacji nietypowych zagrożeń wynikających z funkcjonowania wśród globalnej konkurencji oraz turbulentnego otoczenia. Niepewność, będąca następstwem funkcjonowania w tego rodzaju otoczeniu, sprawia, iż za źródło przewagi konkurencyjnej hotele uznają powiązania sieciowe oraz systematycznie kreowane sieci franchisingowe. Celem niniejszego opracowania jest weryfikacja i możliwość implementacji podejścia sieciowego w procesie kształtowania przewagi konkurencyjnej hoteli na polskim. W wyniku przeprowadzonej analizy literatury przedmiotu oraz badań prowadzonych metodą ankietową wskazano na sposoby osiągania przewagi oraz opracowano rekomendacje dla procesu zarządzania strategicznego hoteli należących do koncernów, a funkcjonujących w sieci. 
W literaturze przedmiotu pojęcie koncernu hotelowego nie jest jednolicie rozumiane. Niemniej jednak istnieje wiele jego odpowiedników: grupa hotelowa, sieć hotelowa, korporacja hotelowa, system hotelowy [Knowles 1996, s. 10]. Sieć hotelowa jest to organizacja, która posiada własną markę (lub marki), może być zarządzana przez tego samego właściciela lub korporację. Zatem jest to grupa zrzeszonych hoteli. Pod pojęciem hotelu zrzeszonego należy rozumieć obiekt, który jest członkiem sieci hotelowej, należy do sieci franchisingowej lub innego systemu integrującego hotele. W konsekwencji tego procesu otrzymuje on specjalne korzyści, głównie przez możliwość korzystania z zasobów i wspólnego systemu rezerwacyjnego [Hotel guidebook Poland \& CEE 2016/2017 2016, s. 13]. Dokonując analizy wewnętrznej organizacji koncernów hotelowych, można zauważyć, że ich struktura jest heterogeniczna. Na tego rodzaju organizacje składają się: sieci hotelowe, biura podróży, firmy transportowe, biura nieruchomości, przedsiębiorstwa gastronomiczne, cateringowe, produkcyjne, podmioty zajmujące się obsługą kasyn, wynajmem samochodów, obrotem bonami żywieniowymi i inne. Zatem działalność koncernów hotelowych obejmuje zróżnicowane obszary biznesu [Sala 2008, s. 134-135].

Istota systemu franchisingowego, do którego należy większość obiektów hotelowych, polega na udzieleniu przez jedną osobę (franczyzodawcę) drugiej osobie (franczyzobiorcy) zezwolenia, które upoważnia franczyzobiorcę do prowadzenia działalności handlowej pod znakiem towarowym/nazwą firmową franczyzodawcy. Ponadto pozwala na wykorzystanie całego pakietu zawierającego wszystkie elementy niezbędne do tego, aby nieprzeszkolona wcześniej osoba mogła być wprowadzona do przedsiębiorstwa zaprojektowanego i utworzonego przez franczyzodawcę oraz by mogła prowadzić to przedsiębiorstwo przy stałej pomocy na z góry ustalonych zasadach [Mendelsohn, Acheson 1992, s. 18]. System franchisingu jest popularną metodą ekspansji korporacji hotelowych, zwłaszcza w Stanach Zjednoczonych. Stanowi on stymulator rozwoju przedsiębiorstw nieposiadających własnego kapitału lub mających trudności ze zgromadzeniem środków niezbędnych do przeprowadzenia procesu inwestycyjnego [Sztorc 2010, s. 94].

Poniżej zaprezentowano wyniki badań zrealizowanych na podstawie kwestionariusza ankiety oraz studium przypadku. Odbywały się one w terminie styczeń-czerwiec 2017 r. Podczas budowy kwestionariusza uwzględniono zagadnienia przedstawione w części teoretycznej artykułu. Dotyczyły one głównie problematyki powiązań sieciowych i kreowania przewagi konkurencyjnej oraz determinant warunkujących rozpoznanie organizacji sieciowych. Kwestionariusz ankiety został przesłany do respondentów, wśród których było: 31 przedstawicieli hoteli koncernu AccorHotels (AH) oraz 25 przedstawicieli hoteli koncernu Best Western International (BW). Odpowiedź zwrotną uzyskano i przyjęto do dalszej analizy od przedstawicieli 24 hoteli sieci AH i 12 respondentów z obiektów BW.

Koncern AH założony został we Francji, aktualnie posiada 4100 obiektów oraz 3000 condo hoteli funkcjonujących w 95 krajach. Należą do niego sieci hotelowe funkcjonujące we wszystkich segmentach rynku: pięciogwiazdkowym (Raffles, 
Fairmont, Sofitel Legend, SO Sofitel, Sofitel), czterogwiazdkowym (MGallery by Sofitel, Pullman, Swissôtel, Grand Mercure, The Sebel), trzygwiazdkowym (Novotel, Mercure, Mama Shelter, adagio, adagio access), dwugwiazdkowym (ibis, ibis styles) oraz jednogwiazdkowym (ibis budget, hotel F1). Na zasadzie licencji udzielonej polskiej Grupie Orbis koncern prowadzi działalność w szesnastu krajach: Bośni i Hercegowinie, Bułgarii, Chorwacji, Czarnogórze, Czechach, Estonii, Litwie, Łotwie, Macedonii, Mołdawii, Polsce, Rumunii, Serbii, Słowacji, Słowenii oraz na Węgrzech. W 2016 r. koncern zajmował szóste miejsce wśród największych korporacji hotelowych na świecie [The Wins of Change 325 Hotels 2016, s. 2-3]. Aktualnie na polskim rynku prowadzi działalność siedemdziesiąt dwa hotele należące do Accor.

Natomiast koncern BW rozpoczął działalność w 1946 r. na terenie Stanów Zjednoczonych. Początkowo przedsiębiorstwo funkcjonowało w charakterze nieformalnej organizacji zrzeszającej hotele, której celem była wzajemna promocja. Po dwudziestu latach od otwarcia pierwszego obiektu organizacja dokonała globalnej ekspansji oraz wprowadziła wspólny system sprzedażowo-marketingowy. Sieć BW wyróżnia się koncentracją wyłącznie na hotelach oferujących standard trzy- i czterogwiazdkowy. Aktualnie do koncernu należy 3677 hoteli, które dysponują 293059 pokojami. Koncern zajmuje dziesiąte miejsce wśród największych korporacji hotelowych na świecie [The Wins of Change 325 Hotels 2016, s. 3]. Na polskim rynku funkcjonuje 25 hoteli w standardzie czterogwiazdkowym (marki Best Western Plus oraz Best Western Premier) oraz trzygwiazdkowym (marka Best Western), które zlokalizowane są w 17 miastach.

W badaniach uczestniczyli wyłącznie przedstawiciele niezależnych hoteli, które przystąpiły do badanych sieci hotelowych na zasadzie franchisingu (100\%). Aktualnie na polskim rynku sieci franchisingowe stanowią drugą po własności (58\%) najpopularniejszą formę prowadzenia działalności hotelowej (21\%) - pozostałe to zarządzanie $(15 \%)$ oraz dzierżawa $(5 \%)$ (rys. 1$)$.

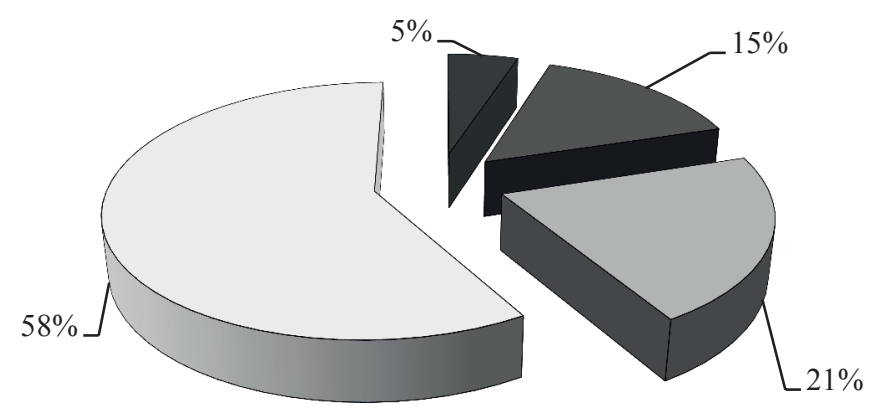

口Dzierżawa $\quad$ Zarządzanie $\quad$ Franchising $\quad$ WWasność

Rys. 1. Formy zarządzania hotelami w Polsce (2016 r.)

Źródło: [Hotel guidebook Poland \& CEE 2016/2017 2016, s. 38]. 
W badaniach dominowali respondenci, których przedsiębiorstwa należą do prywatnych inwestorów (ponad 98\% próby). Strukturę analizowanych hoteli stanowiły obiekty należące do grupy małych i średnich przedsiębiorstw. Tego rodzaju dobór próby stanowił priorytet prowadzonych badań. Hotele zmierzające do osiągnięcia efektu synergii poszukują nowych metod obrony przed konkurencją ze strony globalnych korporacji. Dlatego też podejmują działania polegające na implementacji strategii współpracy oraz kreowaniu więzi organizacyjnych w strukturach sieciowych. Pierwsze stadium badań dotyczyło analizy i oceny stopnia wykorzystania elementów procesu kształtowania przewagi konkurencyjnej z wykorzystaniem organizacji sieciowych (skala od 1 do 5) (zob. tab. 2).

Tabela 2. Przewaga konkurencyjna sieci hotelowych AH i BW

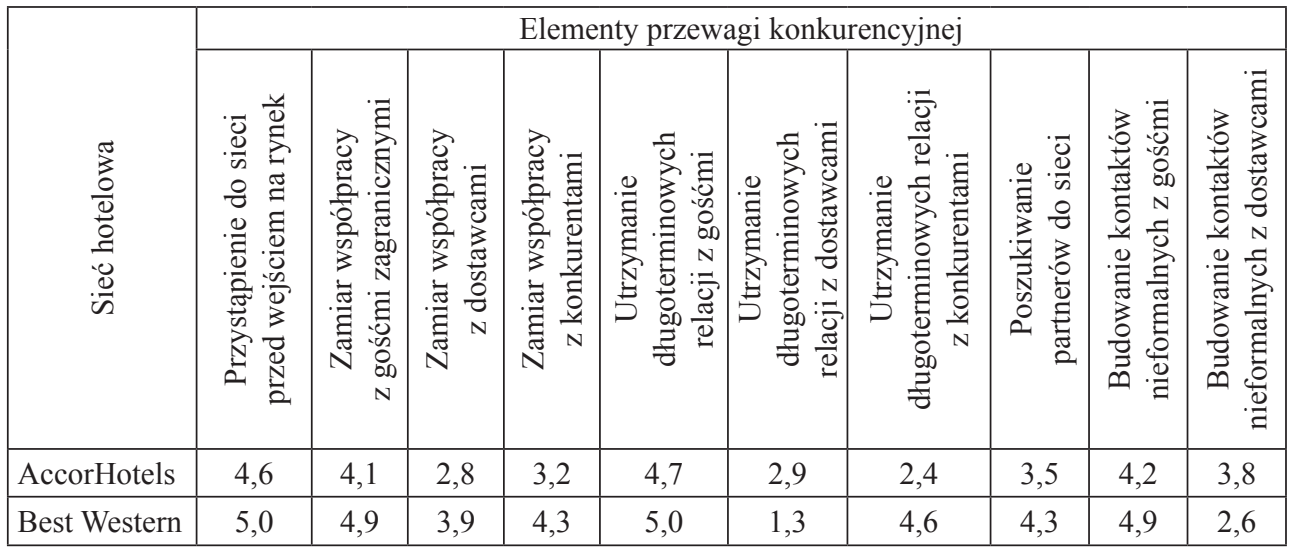

Źródło: opracowanie własne na podstawie przeprowadzonych badań.

Z tabeli 2 wynika, że respondenci przystępują do sieci zazwyczaj przed rozpoczęciem działalności i zorientowani są na współpracę z gośćmi zagranicznymi oraz konkurentami. Kolejny etap badań pozwolił na stwierdzenie, iż respondenci dostrzegają korzyści z przystąpienia do sieci. Wskazane ewenementy zgodne są ze wskazanymi w literaturze przedmiotu. Wśród pozytywnych okoliczności przystąpienia do sieci respondenci wskazali dostęp do zasobów (84\% AH; 91\% BW) oraz nowych segmentów nabywców (53\% AH; 78\% BW) (rys. 2).

Kolejnym elementem, który został wskazany przez większość respondentów, był transfer wiedzy (42\% AH; 58\% BW) wynikający z dostępu do zasobów. Z kolei sporadycznie wymienianym atutem była możliwość uzyskania dodatkowych źródeł finansowania $(7 \% \mathrm{AH} ; 3 \% \mathrm{BW})$. Oprócz pozytywnych cech funkcjonowania w strukturze sieciowej wskazano także na negatywne efekty prowadzenia działalności w sieci franchisingowej. Według respondentów największe zagrożenie stanowi dyktowanie warunków współpracy (82\% AH; 96\% BW). Wśród kolejnych mankamentów wymieniono współzależność od kontrahentów, mniejszą zdolność do funkcjonowania oraz ograniczenie siły przetargowej w stosunku do dostawców (rys. 3). 


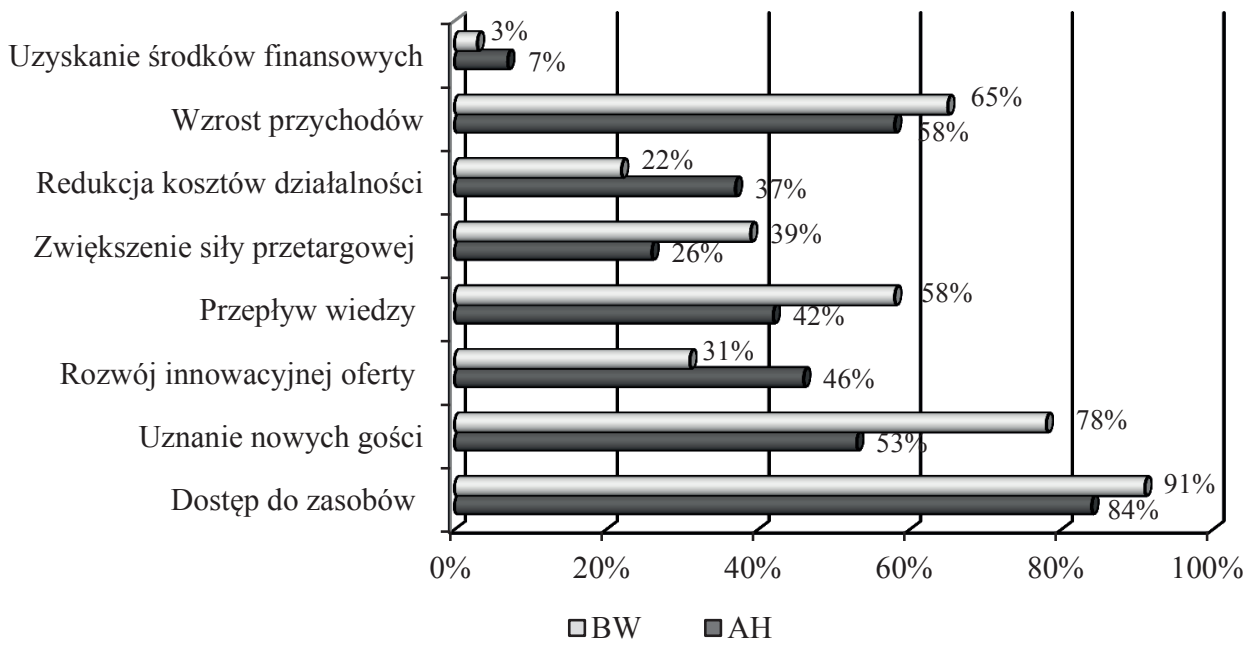

Rys. 2. Korzystne przejawy funkcjonowania w strukturze sieciowej

Źródło: opracowanie własne na podstawie przeprowadzonych badań.

Zmniejszenie przychodów

Podwyższenie kosztów funkcjonowania

Ograniczenie siły przetargowej

Zmniejszona elastyczność funkcjonowania

Współzależność od kooperantów

Dominacja kosztów nad zaletami kooperacji

Zacieranie się granic odpowiedzialności

Dyktowanie kontaktów współracy

Dyktowanie warunków współpracy

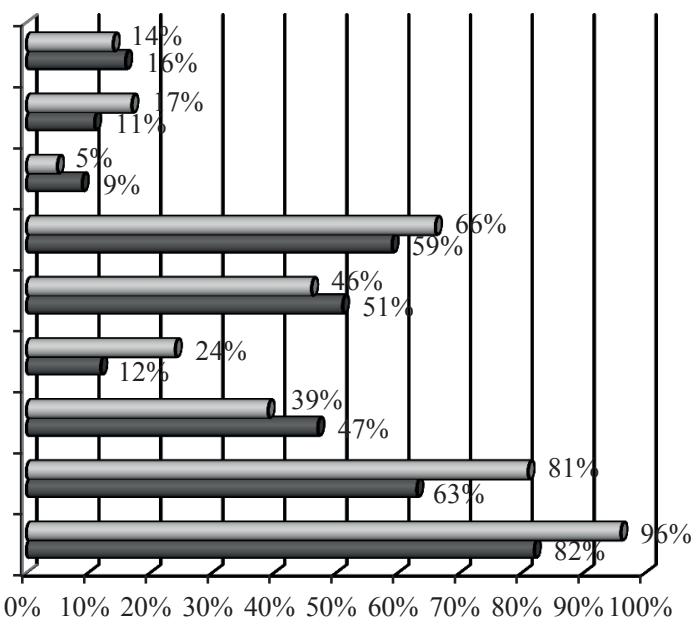

$\square B W \quad \square \mathrm{AH}$

Rys. 3. Negatywne przejawy funkcjonowania w strukturze sieciowej

Źródło: opracowanie własne na podstawie przeprowadzonych badań.

Natomiast wśród elementów zniechęcających do pozostania w sieci i tworzenia nowych struktur międzyorganizacyjnych wymieniono: brak środków finansowych, brak zaufania, odmienność wizji, różnice kulturowe, niezgodność strategii z planami obiektu, różnokierunkowość kompetencji oraz wiedzy (rys. 4). 
Niepokój przed kontrolą
Przewodzenie jednego podmiotu

Różnokierunkowość kompetencji i wiedzy

Niezgodność strategii

Różnice kulturowe

Odmienność celów i wizji

Brak zaufania

Brak środków finnasowych

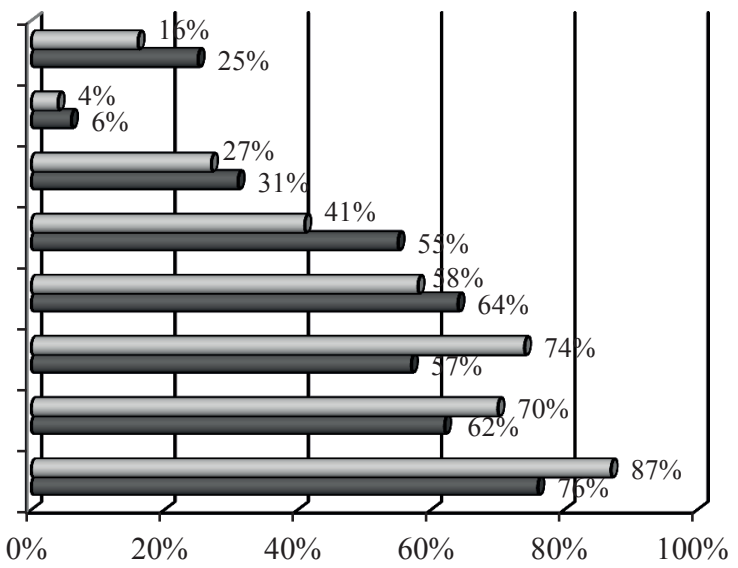

$\square \mathrm{BW} \quad \square \mathrm{AH}$

Rys. 4. Okoliczności demotywujące do przystąpienia do sieci międzyorganizacyjnej

Źródło: opracowanie własne na podstawie przeprowadzonych badań.

Na podstawie przeprowadzonych badań można określić rekomendacje dla zarządzania strategicznego. Dotyczą one wdrażania koncepcji organizacji sieciowej w procesie budowania przewagi konkurencyjnej przez przedsiębiorstwa hotelowe. Wśród kluczowych wytycznych należy wymienić:

- wyznaczenie i sformułowanie wzorca kooperacji dla podmiotów należących do sieci,

- ustalenie płaszczyzny samodzielności w ustalaniu celów i strategii,

- ustalenie zakresu niezależności w podejmowaniu decyzji przez organizacje należące do sieci,

- wybór kluczowych kompetencji, które zostaną wykorzystane w sposób skoordynowany i umożliwiający wspólne korzystanie z zasobów sieci,

- ustalenie zakresu wzajemnego dostosowania się partnerów w sieci,

- wykorzystanie potencjału strategicznego partnerów celem osiągnięcia potencjału synergicznego, który tworzy wartość dodaną,

- określenie zasad podziału zadań wśród poszczególnych partnerów sieci stosownie do posiadanych kompetencji,

- rozpoznanie i sklasyfikowanie mierników oszacowania przewag występujących w procesie implementacji strategii, które wynikają z nawiązanej współpracy sieciowej,

- wykreowanie modelu biznesu adekwatnego do możliwości współdziałania bądź potencjalnego konkurowania podmiotów tworzących sieć,

- ustalenie zasięgu i zakresu partnerstwa oraz wzajemnych zależności uczestników sieci, 
- opracowanie koncepcji tworzenia zasad, norm oraz wartości wśród podmiotów funkcjonujących w sieci,

- określenie zasad podziału renty relacyjnej wśród uczestników sieci,

- zdefiniowanie zasad podporządkowania się regułom współpracy z kooperantami w rezultacie przekształceń wynikających z transformacji otoczenia społeczno-gospodarczego,

- wytypowanie kluczowych przesłanek wpływających na proces implementacji strategii podmiotu będącego elementem organizacji sieciowej,

- wyznaczenie mechanizmów niezbędnych do podtrzymywania relacji z partnerami w sieci w celu określenia granicy przekazywanej informacji pomiędzy podmiotami oraz zasad udostępniania wiedzy i kompetencji,

- wyznaczenie reguł przekazywania informacji o znaczeniu strategicznym dla organizacji sieciowej,

- określenie zakresu współdziałania jako alternatywy dla konkurowania podmiotów tworzących sieć.

Sposoby kreowania i rozwijania przez koncerny sieci hotelowych polegają nie tylko na optymalizacji działań, ale stanowią one kluczowe źródło ich wartości. Większość globalnych koncernów funkcjonujących na polskim rynku hotelowym realizuje strategię polegają na tworzeniu trwałych relacji z podmiotami. Jej rezultat stanowi potencjał tworzenia wartości (m.in. efekt synergii, nowe obszary pozyskania wiedzy i kompetencji). Współczesne zarządzanie hotelem opiera się nie tylko na własnych zasobach, ale także umiejętności ich rozpoznania i uzyskania. W następstwie posiadanych kompetencji, które niezbędne są do tworzenia sieci, podmiot może pozyskać zasoby dotychczas niebędące pod jego bezpośrednią kontrolą. Tym samym może uzyskać przewagę konkurencyjną nad obiektami nietworzącymi tego typu relacji.

\section{Zakończenie}

Dokonując podsumowania przedstawionych badań i analiz, należy stwierdzić, iż obecna perspektywa badawcza zagadnień konkurencyjności oraz przewagi konkurencyjnej koncentruje się wokół relacji sieciowych. Powiązania międzyorganizacyjne przedsiębiorstw hotelowych traktowane są jako potencjalne źródło przewagi konkurencyjnej. Dlatego też istnieje konieczność opracowania metodyki przeprowadzania badania tych zagadnień z perspektywy przełożenia pomiaru przewagi na rzeczywiste korzyści wynikające z tytułu nawiązania relacji sieciowych.

Współczesne przedsiębiorstwa funkcjonujące w sytuacji niestabilności i nieprzewidywalności otoczenia ulegają naciskom obniżania kosztów oraz dostosowania oferty do wymagań nabywców. Na skutek połączenia zasobów oraz umiejętności kooperujące ze sobą hotele mogą osiągnąc znaczną przewagę przez elastyczność funkcjonowania. Zazwyczaj zapewniają wysokiej jakości usługi/produkty, które odpowiadają wymaganiom gości oraz przewyższają poziom oferowanych przez konkurentów. 
Z przeprowadzonych badań wynika, iż funkcjonowanie przedsiębiorstwa hotelowego w sieci przynosi korzyści dla kooperujących organizacji. Celem osiągnięcia rynkowego zwycięstwa proces zarządzania strategicznego w hotelu należącym do sieci zobowiązuje do koncentracji procedur biznesowych, technologicznych oraz dystrybucyjnych. Zaprezentowana $\mathrm{w}$ artykule problematyka identyfikacji koncepcji organizacji sieciowej z perspektywy zdobywania przewagi konkurencyjnej stanowi podstawę dalszego rozpoznania tego rodzaju płaszczyzny badawczej. Wzmożone zainteresowanie organizacjami sieciowymi oraz występujące przy ich tworzeniu luki motywują do prowadzenia dalszych prac badawczych w tej tematyce.

\section{Literatura}

Adamik A., 2008, Creating of Competitive Advantage Based on Cooperation, Politechnika Łódzka, Łódź.

Bakier B., Meredyk K., 2000, Istota i mechanizmy konkurencyjności, [w:] Konkurencyjność gospodarki polskiej a rola państw przed akcesja do Unii Europejskiej, H. Podedworny, I. Grabowski, H. Wnorowski (red.), Wydawnictwo Uniwersytetu w Białymstoku, Białystok.

Barney J.B., 2011, Gaining and Sustaining Competitive Advantage, Pearson Education, New Jersey.

Bartnicki M., 2001, Dylematy i pułapki współczesnego zarządzania, Gnome, Katowice.

Benassi M., Greve A., Harkola J., 1999, Looking for a network organization: The case of GESTO, Journal of Market Focused Management, no. 4.

Brilman, J., 2002, Nowoczesne koncepcje i metody zarządzania, PWE, Warszawa.

Chwistecka-Dudek H., 1993, Strategie dywersyfikacji przedsiębiorstw, AE Katowice, Katowice.

Czakon W., 2012, Sieci w zarządzaniu strategicznym, Wolters Kluwer, Warszawa.

Drabik I., 2016, Podejście sieciowe $w$ zarządzaniu przedsiębiorstwem na rynkach zagranicznych, Studia i Prace WNEiZ US nr 44, Uniwersytet Szczeciński, Szczecin.

Dyer J., Singh H., 1998, The relational view: Cooperative strategy and sources of interorganizational competitive advantage, Academy of Management Review, no. 23.

Glückler J., Dehning W., Janneck M., Armbrüster T., 2012, Unternehmensnetzwerke: Architekturen, Strukturen und Strategien, Springer Gabler Verlag, Berlin.

Gorynia M., 2000, Zachowania przedsiębiorstw w okresie transformacji. Mikroekonomia przejścia, AE Poznań, Poznań.

Gorynia M., 2010, Konkurencyjność w ujęciu mikroekonomicznym, [w:] M. Gorynia, E. Łaźniewska, Kompendium wiedzy o konkurencyjności, PWN, Warszawa.

Harasim W., 2012, Wykorzystanie kapitatu intelektualnego w zarządzaniu organizacja inteligentna dla tworzenia przewagi konkurencyjnej, WSP, Warszawa.

Hotel guidebook Poland \& CEE 2016/2017 (Hotel, Tourism and Leisure), 2016, Horwath HTL, Warszawa.

Knowles T., 1996, Corporate Strategy for Hospitality, Longman.

Krupski R., 2005, Zarządzanie przedsiębiorstwem $w$ turbulentnym otoczeniu. Ku superelastycznej organizacji, PWE, Warszawa.

Mendelsohn M., Acheson D., 1992, Franchising, Poltext, Warszawa.

Mikołajek-Gocejna M., 2011, Wybrane teorie wyjaśniajace powstawanie i funkcjonowanie organizacji sieciowych, Szkoła Główna Handlowa Zeszyty Naukowe nr 32. Kolegium Gospodarki Światowej.

Mikuła B., 2006, Organizacje oparte na wiedzy, AE Kraków, Kraków.

Penc-Pietrzak I., 2015, Charakterystyka zdolności dynamicznych przedsiębiorstwa w warunkach hiperkonkurencji, Studia Ekonomiczne. Zeszyty Naukowe Uniwersytetu Ekonomicznego w Katowicach, nr 229. 
Pietruszka-Otryl A., 2007, Organizacja sieciowa, [w:] Podstawy zarządzania wiedza w gospodarce opartej na wiedzy, B. Mikuła, A. Pietruszka-Otryl, A. Potocki (red.), Difin, Warszawa.

Piwoni-Krzeszowska E., 2015, Paradygmat relacyjny czy sieciowy - wytanianie się czy występowanie?, [w:] Zarzadzanie strategiczne. Strategie sieci i przedsiębiorstw w sieci, R. Krupski (red.), Wydawnictwo Wałbrzyskiej Wyższej Szkoły Zarządzania i Przedsiębiorczości w Wałbrzychu, Wałbrzych.

Sala J., 2008, Formy wspótczesnego hotelarstwa, UEK, Kraków.

Stankiewicz M.J., 2005, Konkurencyjność przedsiębiorstwa. Budowanie konkurencyjności przedsiębiorstwa w warunkach globalizacji, Towarzystwo Naukowe Organizacji i Kierowania, Torun.

Sztorc M., 2010, Franchising jako instrument podnoszenia konkurencyjności firm w hotelarstwie, Zeszyty Naukowe Uniwersytetu Ekonomicznego w Krakowie, nr 825.

Śmigielska G., 2007, Kreowanie przewagi konkurencyjnej w handlu detalicznym, AE, Kraków.

The Wins of Change 325 Hotels, 2016, France.

Thorelli H.B., 1986, Networks: Between markets and hierarchie, Strategic Management Journal, no. 7. Todeva E., 2010, Management of International Business Networks, Routledge, Oxford.

Wiatrak A.P., 2003, Organizacje sieciowe - istota ich działania i zarządzania, Współczesne Zarządzanie.

Wyrwicka M.K. 2011, Sieciowość jako baza współczesnej kooperacji, [w:] Nowe tendencje w zarzadzaniu, M. Pawlak (red.), Wydawnictwo KUL, Lublin.

Yonggang, S., 2006, Study on Competitiveness of SCEC, Shanghai Maritime University, Shanghai Shi.

Zentes J., Swoboda B., Morschett D., 2005, Kooperationen, Allianzen, Netzwerke. Grundlagen-Ansätze-Perspektiven, Auflage Verlag, Wiesbaden. 